\title{
Composition and trophic structure of the ichthyofauna from a stream downriver from Santo Antonio Falls in the Madeira River, Porto Velho, RO
}

\author{
Túlio Raimundo de Araújo ${ }^{1}$, Ariana Cella Ribeiro ${ }^{1}$, \\ Carolina Rodrigues da Costa Doria ${ }^{1} \&$ Gislene Torrente-Vilara ${ }^{2}$ \\ ${ }^{1}$ Laboratório de Ictiologia e Pesca - LABCTIO, Universidade Federal de Rondônia - UNIR, \\ BR 364, Km 9,5, sentido Acre, CEP 78900-000, Porto Velho, RO, Brazil \\ ${ }^{2}$ Instituto Nacional de Pesquisas da Amazônia - INPA, \\ Av. André Araújo, 2936, Aleixo, CEP 69083-970, Manaus, AM, Brazil \\ ${ }^{3}$ Autor para correspondência: Túlio Raimundo de Araújo, e-mail tuliobio@yahoo.com.br
}

ARAÚJO, T.R., CELLA-RIBEIRO, A., DORIA, C.R.C. \& TORRENTE-VILARA, G.T. Ichthyofauna of the stream in the Madeira River. Biota Neotrop., (9)3: http://www.biotaneotropica.org.br/v9n3/en/ abstract?article+bn00209032009.

\begin{abstract}
Belmont Stream is the main tributary of the Madeira River in the area immediately downriver from the Santo Antonio Fall. Samplings were carried out using gill nets in the mouth of this stream between May 2005 and April 2006 and resulted in a list of 74 species. The analyses included values of composition, constancy of occurrence, species richness, abundance, Catch Per Unit of Effort and trophic structure about the ten most abundant species. Characiformes and Siluriformes were dominant order in the samples and Curimatidae (popularly known as "branquinhas") was the most abundant family, represented by Psectrogaster rutiloides (32.57\% of the collected specimens), Potamorhina altamazonica (10.72\%), and Potamorhina latior (7.79\%). The most of species were considered accessory and accidental and richness suggests high values in the rising and high water. Belmont maybe considered as a moderate richness when compared to those found for others Amazon rivers. Detritivorous fishes composed $60 \%$ of the assemblage and the constancy of the most abundant species of this family suggests Belmont as an important area to these migratory fishes.
\end{abstract}

Keywords: richness, dominance, CPUE, migratory route, Amazon.

ARAÚJO, T.R., CELLA-RIBEIRO, A., DORIA, C.R.C. \& TORRENTE-VILARA, G.T. Composição e estrutura trófica da ictiofauna de um igarapé a jusante da cachoeira de Santo Antônio no Rio Madeira, Porto Velho, RO. Biota Neotrop.: http://www.biotaneotropica.org.br/v9n3/pt/abstract?article+bn00209032009.

Resumo: O igarapé Belmont localiza-se a cerca de $30 \mathrm{~km}$ de Porto Velho e é o principal afluente do rio Madeira na área imediatamente a jusante da cachoeira de Santo Antonio. No período compreendido entre maio de 2005 a abril de 2006, dez coletas realizadas na foz deste igarapé geraram uma lista com 74 espécies coletadas por malhadeiras. As análises incluem características físico-químicas do igarapé estudado, valores de riqueza, composição, constância, estrutura trófica da assembléia de peixes e valores de CPUE. O predomínio das ordens Characiformes e Siluriformes confirma o esperado para a Amazônia. A família Curimatidae foi a mais abundante, representada por Psectrogaster rutiloides (32,57\%), Potamorhina altamazonica (10,72\%) e Potamorhina latior (7,79\%), popularmente conhecidas como branquinhas. A riqueza e constância de algumas espécies sugerem um papel especial da área no que diz respeito à transposição das corredeiras pelas espécies. Conclui-se que a estrutura e a composição da ictiofauna na área estudada do igarapé Belmont é marcada por espécies migradoras detritívoras, possivelmente em função do papel do rio Madeira nas rotas migratórias.

Palavras-chave: riqueza, dominância, CPUE, rotas migratórias, Amazônia. 


\section{Introduction}

In the Amazon, the remarkable richness of the ichthyofauna reflects the complexity of its aquatic ecosystems (Goulding 1980, 1988, Ferreira et al. 1993, Lowe-McConnell 1999). Due to the enormous area of the basin, it is very difficult to obtain systematized knowledge with respect to the ichthyofauna (Bohlke et al. 1978). In general, studies on the Amazonian ichthyofauna are temporally restricted and geographically concentrated in the Central Amazon (Junk et al. 1983, Merona \& Bittencourt 1993, Sabino \& Zuanon 1998, Siqueira-Souza \& Freitas 2004, Pazin et al. 2006), Trombetas River (Ferreira et al. 1993) and the estuary region (Honda 1974, Vieira \& Gery 1979). There is few biological and ecological information about the fish fauna of the Brazilian part of the Madeira River basin, the largest and most complex Amazon River tributary (Goulding et al. 2003) and that harbors a very high species richness (Torrente-Vilara et al. 2005, Rapp Py-Daniel et al. 2007).

A search in the literature about the Madeira River and its tributaries in the Brazilian and Bolivian territory highlights Goulding's (1979) seminal research about the fisheries in that basin. Later, inventory studies were carried out by Lauzanne \& Loubens (1985), Santos (1986, 1991), Lauzanne et al. (1990), Loubens et al. (1992), Viana (1999), Barthem et al. (2003), Pouilly \& Miranda (2003), Pouilly et al. (2003), Pouilly \& Rodrigues (2004), Pouilly et al. (2004), Torrente-Vilara et al. (2005), Camargo \& Giarrizzo (2007) and Rapp Py-Daniel et al. (2007), some of them containing important ecological information about the fish assemblages. However, only Torrente-Vilara et al. (2005), a report study, presents data about the general composition of the fish community near the area of the rapids of Santo Antonio Falls.

Waterfalls and rapids can represent an important physical barrier to be crossed by the aquatic fauna (Robinson et al. 2005), especially for the fish species that carries out longitudinal migrations in the river channels. The first waterfall of the Madeira River rapids to be crossed during the longitudinal migration of the fish is the Santo Antonio Falls. This waterfall, together with the Teotônio Falls located upriver, markedly distinguishes the high and encased portion of the Madeira River from the floodplains downriver (Souza-Filho et al. 1999). This set of waterfalls and rapids can limit the distribution of certain species of the ichthyofauna (e.g. Zanata \& Toledo-Piza 2004).

Apart from the historic use of this area of the Madeira River for gold panning (Bastos et al. 2007) and the impacts possibly caused by the construction of a grain port in Porto Velho in the 1990s, two hydroelectric power plants are under construction The Santo Antonio Falls will be the first artificial barrier on that portion of the river, flooding the Teotônio Falls immediately upriver. The necessity to generate a historical data about the fish fauna before the damming motivated the study of the composition and structure of the ichthyofauna at the transition zone between the rapids stretch and the floodplains of the Madeira River. These data will serve as a comparison for future studies to verify the alterations to the system, thereby contributing to the delimitation of the impacts and providing information about the ecological importance of the area immediately downriver from the Santo Antonio Falls to the fish fauna of the Madeira River.

\section{Material and Methods}

\section{Study area}

The Madeira River is the largest tributary of the Amazon River in terms of sediment discharge and the second largest in water discharge (McClain et al. 1995, Latrubesse et al. 2005). Approximately $1,600 \mathrm{~km}$ from its confluence with the Amazon River there is a series of rapids that seems to represent an important obstacle in the migratory route of some fish species (Keller 1874, Goulding 1979).

Annual Madeira River level variation between dry and flood season ranges from 11 to $13 \mathrm{~m}$ and it is distinct from values observed in central Amazon (Bittencourt \& Amadio 2005). The flood pulse in upper Madeira River area presented a long rising and a short high water period during sampling (pers.obs.). The few tributaries located immediately up- and downriver from the rapids stretch show flood regimes and limnological characteristics typical of small to mediumsized water courses (Torrente-Vilara et al. 2008) and an effect of Madeira River channel flood pulse. Amazonian streams are narrow and shallow water courses characterized by acidic waters and high concentrations of dissolved oxygen (e.g. Walker 1991, Soares 1993, Mendonça et al. 2005). The flood regime of the streams is associated with the daily rainfall (Walker 1995, Espírito-Santo 2008), and the biological production of these aquatic systems is very dependent on the input of allochthonous nutrients (Walker 1995, Lowe-McConnell 1999, Carvalho 2008). In the Amazon, streams constitute one of the most important components of the regional drainage network (Junk et al. 1983, Walker 1991, 1995).

Belmont stream, located near Porto Velho city in Rondônia State, Brazil, was chosen as the study area because it is one of the largest tributaries of the Madeira River downriver from Santo Antonio Falls, and in function of its fish species richness (Torrente-Vilara 2005). Located about $25 \mathrm{~km}$ downriver from Santo Antonio Falls, Belmont stream is about $13.5 \mathrm{~km}$ long and about $8 \mathrm{~m}$ deep at the peak of the flooding period. Part of its headwaters is in the urban perimeter of Porto Velho (Figure 1) and has been affected by building and street constructions, channel blockage and pollution (Menezes 2007). The central portion of the stream crosses the Natural Park of Porto Velho, a well preserved area that partially protects the basin. Downstream from the Park towards its mouth in the Madeira River, the water of Belmont stream is used for a variety of activities, from agriculture to animal farming (pigs, birds and cattle), as well as recreational activities (Menezes 2007). The sampling area utilized in the present study comprises $1 \mathrm{~km}$ stretch of the Belmont stream upstream from its mouth with the Madeira River.

\section{Sampling}

Sampling was carried out monthly between May 2005 and April 2006. Fishes were caught using two sets of 13 gill nets $(30,40,50$, $60,70,80,90,100,120,140,160,180$, and $200 \mathrm{~mm}$ mesh size), giving a total capture area of $650 \mathrm{~m}^{2}$. The gill nets were set in appropriate sites in the stream for 24 hours, with fish being removed every 6 hours. Captured fishes were taken to the Ichthyology and Fishing Laboratory (LIP) of the Federal University of Rondônia (UNIR). In the lab, they were sorted by species, identified (using taxonomic identification keys and by comparison with specimens deposited in the Collection of Fishes of UNIR), and counted. Each specimen was measured (standard length), with an accuracy of $0.1 \mathrm{~mm}$ and weighted (grams). Voucher specimens were deposited in the fish collection under the numbers UNIR0015, UNIR0025, UNIR0029 - UNIR0080, UNIR0098 - UNIR0104, UNIR0387 - UNIR0400 and UNIR0599.

\section{Environmental data}

In this study the Belmont stream was treated as a sub-basin of Madeira River. The physical characterization of the study area was carried out by using data obtained from different sources. A digital model of the terrain elevation by Shutle Radar Topography Mission (SRTM) version 3 from U.S. Geological Survey (USGS) was used to generate the data: size area, the river channel stretches (drainage system) measured by kilometers, altitude values and percent of deforested area (see methods in Hess, 2003). The Belmont stream has an 


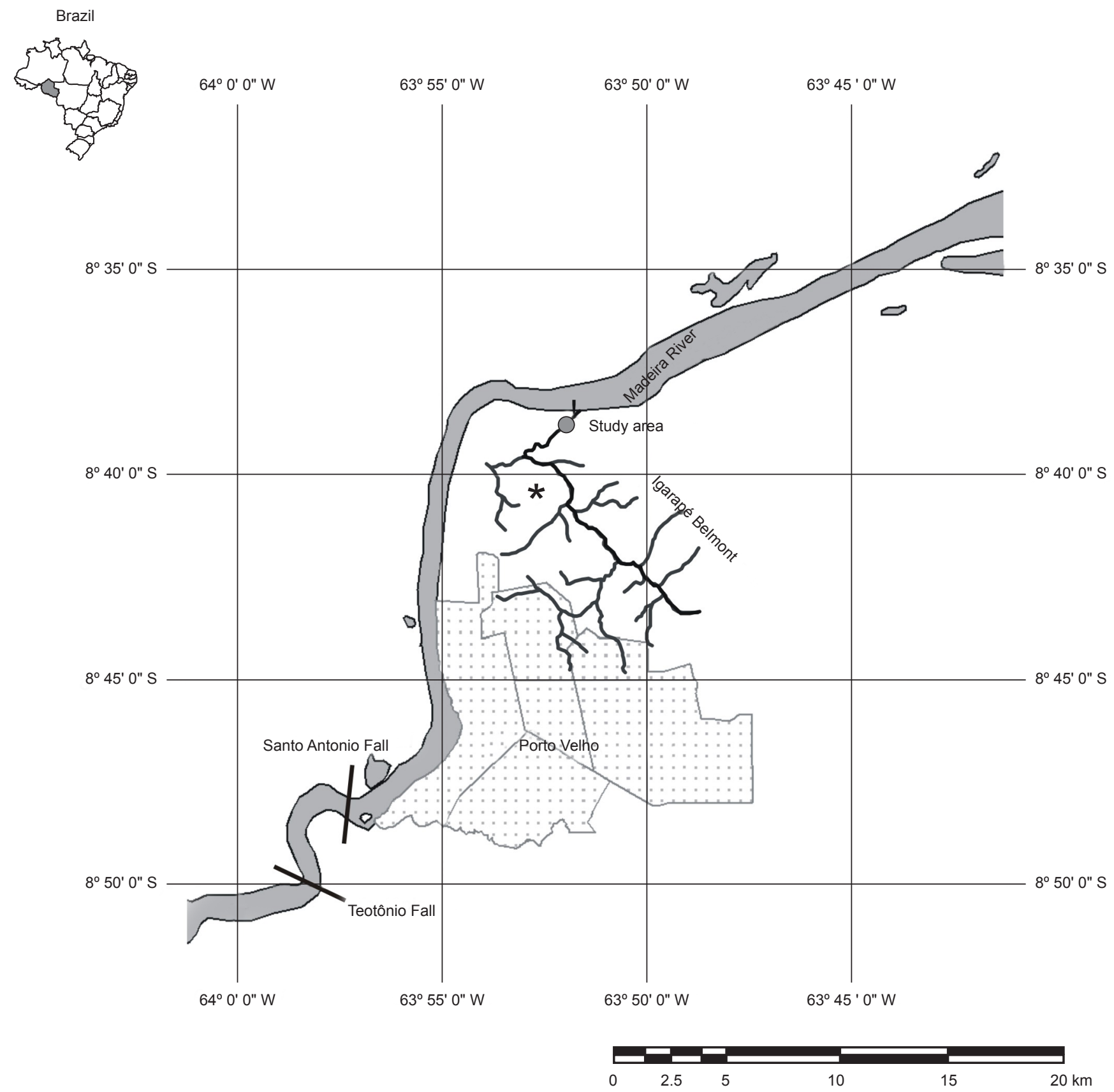

Figure 1. Map of the Belmont stream drainage area, a tributary of Madeira River, showing the sampling area near Porto Velho, in Rondônia.*Natural Park area in Porto Velho.

Figura 1. Mapa da área de drenagem do igarapé Belmont, um tributário do Rio Madeira, mostrando a área próxima a Porto Velho, em Rondônia. * Área do Parque Natural em Porto Velho.

area of $63,336 \mathrm{~km}^{2}$ with drainage of 2 kilometers long. The altitude mean is $84 \mathrm{~m}$ and range from 57 to $105 \mathrm{~m}$. The deforested area covers $71 \%$ of the sub-basin and the small remaining forest area (about 29\%) could be represented by open Ombrophilous Forest, dominated by large palm trees in low or sub-montana lands.

Limnological data $(\mathrm{pH}$, dissolved oxygen, conductivity and water temperature) was obtained in May and September 2007, to represent the high and low water respectively, by using portable electronic equipment (Schott Landylab). Due to the absence of a hydrometric station at Belmont stream, hydrological level curves of the Madeira River registered by PORTOBRAS in Porto Velho was utilized in the environmental analyses.

\section{Data analysis}

The hydrological periods were identified as: rising water (November to February), high water (March to April), falling water (May to July) and low water (August to September). Due to different number of months at each hydrological period, data was analyzed 
by individual month to become comparable. A list of fish species and their respective abundance enabled us to analyze richness, composition and constancy of occurrence. The constancy of occurrence was determined based on the percentage of sampling month in which each species occurred (cf. Dajoz 1973). The abundance was presented by the capture per unit of effort (CPUE) by number and biomass, in grams. The trophic structure was determined by trophic guilds, using the ten most abundant species of the assemblage which represents $80 \%$ of the total capture. Species trophic guilds were obtained from secondary data in the scientific literature as following: Psectrogaster rutiloides, Potamorhina altamazonica, Potamorhina latior, Prochilodus nigricans, Psectrogaster amazonica and Loricaria cataphracta) were considered detritivorous (Soares et al. 1986, Santos 1991, Yossa \& Araújo-Lima 1998, Santos et al. 2006), feeding mainly on semi-decomposed organic material and animal or vegetable microorganisms deposited on the bottom or feeding on a substrate forming a periphyton that grows on the rocks (Wetzel 1975, Yossa \& Araújo-Lima 1998); Triportheus angulatus is an omnivorous species which diet is based on animal and vegetable items with no preference for a item (Santos 1991, Santos et al. 2006, Yamamoto et al. 2004); Mylossoma duriventre feeds basically on fruits, seeds and aquatic insect larvae and is considered a herbivorous species (Goulding 1979, Santos 1991); Raphiodon vulpinus and Sorubim lima whose feed on other fishes (Santos 1991, Almeida et al. 1997, Hahn et al. 1998, Santos et al. 2006) were considered piscivorous species.

\section{Results}

Belmont stream is a black-clear water stream but its limnological characteristics are similar to other clear water streams described for the Amazon. Mean values and range from low to high water periods were 6.1 (6.06-6.15) for $\mathrm{pH}$; temperature was $27.6^{\circ} \mathrm{C}\left(28.7-26.5^{\circ} \mathrm{C}\right)$ and $3.9 \mathrm{mg} . \mathrm{L}^{-1}$ (1.4-6.4 mg.. $\left.\mathrm{L}^{-1}\right)$ for dissolved oxygen. However, the mouth of Belmont stream is strongly influenced by the river channel for most of the year, justifying the high conductivity which ranges from 38.3 to $40.5 \mu \mathrm{S} \mathrm{cm}^{-1}$ (mean: $39.4 \mu \mathrm{S} \mathrm{cm}^{-1}$ ).

Overall, 2,042 fish specimens collected belong to 5 orders, 18 families and 74 species (Table 1). The most abundant order was Characiformes (88\%), followed by Siluriformes (10\%). Perciformes, Clupeiformes and Gymnotiformes were secondary taxonomic groups and represented only $2 \%$ of the specimens in the samples. The mainly families were: Curimatidae (56\%), Characidae (19\%), Loricariidae and Cynodontidae (5\%) and Prochilodontidae and Pimelodidae (4\%). All the other families, represented $7 \%$ of the specimens captured (Table 1). The Curimatidae family was represented by more than $50 \%$ of the specimens in most of the samples, except during the falling water, when there was a predominance of Characidae family. The Curimatidae fish can be represented especially by three species of "branquinha": $P$. rutiloides $(32.57 \%)$, $P$. altamazonica (10.72\%) and P. latior (7.79\%). About frequency of species, 15 were considered constant $(\mathrm{C}>50 \%), 12$ accessory $(\mathrm{C}>25<50 \%)$ but the assemblage was mostly represented by 47 species classified as accidental $(\mathrm{C}<25 \%)$.

The total number of captures per unit of effort (CPUE) obtained in Belmont stream was 30 individuals and $2,800 \mathrm{~g}$ per $100 / \mathrm{m}^{2} / 24$ hours. CPUE values changed among months; however, it is possible to observe that the greatest values occurred between September and

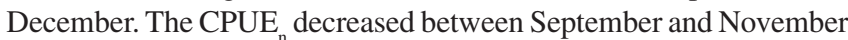
while there was a simultaneous increase in the $\mathrm{CPUE}_{\mathrm{b}}$ value. Low values to $\mathrm{CPUE}_{\mathrm{n}}$ and $\mathrm{CPUE}_{\mathrm{b}}$ occurred from February to August, during the high and falling water periods (Figure 2). Highest values for CPUE were due to the most abundant species in the samplings: $P$. rutiloides, $P$. altamazonica and $P$. latior.
Species richness varied between 15 and 29 among samples. Highest values occurred in November, February and April representing the rising and high water periods (Table 2).

There were ten species with more than 35 specimens in the samples $(\mathrm{N}>35)$ representing about $80 \%$ of the assemblage: $P$. rutiloides, P. altamazonica, P.latior, P. nigricans, P. amazonica, L. cataphracta, T. angulatus, $M$. duriventre, $R$. vulpinus and $S$. lima. Those species represent the trophic quantitative structure of the assemblage with $60 \%$ detritivorous, $7 \%$ omnivorous, $7 \%$ piscivorous and $6 \%$ herbivorous.

\section{Discussion}

Belmont is a typically small stream in the rapids of Madeira River basin. The conductivity, $\mathrm{pH}$ and temperature exhibited greater values when compared with streams in the Central Amazon (Furch \& Junk 1997, Mendonça et al. 2005). Stream environments are characterized by low conductivity and $\mathrm{pH}$ and high values of dissolved oxygen. The high conductivity confirms the strong influence of the river channel, independently of the hydrological period. Oxygen values measured in Belmont were lower than what expected for environments near rapids as shown by Casatti \& Castro (2006). The higher temperature than usually obtained from studies in streams (Mendonça et al. 2005, Carvalho 2008, Espírito-Santo et al. 2008), is possibly due to the 70\% of deforestation of the area (Silva Dias et al. 2005).

The predominance of Otophysi fish is in agreement with the expected for the Amazon (Nelson 1994, Lowe-McConnell 1999) represented by Characiformes and Siluriformes which are similar to those obtained for several rivers and streams in the Neotropical region (Roberts 1972, Sabino \& Zuanon 1998, Lowe-McConnell 1999, Castro 1999, Pouilly et al. 2004). The families with the greatest abundance in Belmont were Curimatidae and Characidae, a broadly distributed group throughout the Amazon basin (Britski 1999, Ferreira et al. 1998, Santos et al. 2006).

Species richness and total abundance had high values in the high water, despite the effect of the efficiency of the fishing gear used. Although fishes have relative advantage for escaping from the fishing gear during the high water period, dwelling species were caught in small mesh size gill nets and contributed to increase richness. The richness values observed in Belmont stream are considered moderate when compared to those found for rivers and floodplain systems in Central Amazon (Saint-Paul et al. 2000).

The large number of species characterized as accessory and accidental (59, representing 75\% from the total) demonstrates a seasonal effect on local assemblages (Uieda 1984). Similar results were found for other aquatic systems (Garutti 1988, Penczak et al. 1994, Pavanelli \& Caramaschi 1997, Miranda \& Mazzoni 2003). There are species represented by a few number of individuals in natural conditions of tropical communities (Matthews 1998) and this fact explains the high diversity prevailing in the Amazon (LoweMcConnell 1999), however, the low values of abundance registered in this study remains to be tested.

Psectrogaster rutiloides and P. altamazonica were constant in Belmont; they are migratory (Fernandes 1997) and expected to occur in white water rivers (Santos et al. 2006, Yossa \& Araújo-Lima 1998). They are dominating species, with values up to $30 \%$ are rare in tropical communities (Lowe McConnell 1999) and that happens are usually due to local conditions, such as specific seasonal alterations or colonizing opportunities. Eight of the most abundant species in this study could not be characterized as migratory (Fernandes, 1997) despite our results. Exceptions include L. cataphracta and S. lima, the latter with no biological information in the literature. 
Table 1. Frequency of occurrence of fish species in Belmont stream from May 2005 to April 2006 ( $\Delta$ Constant, $\square$ Accessory, — Accidental).

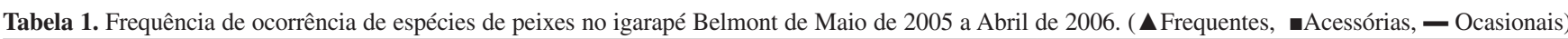

$\begin{array}{lllll}\text { Taxon } & \text { N } & \% & \text { Ls min-max } & \text { Occurrence }\end{array}$

(mm)

\begin{tabular}{|c|c|c|c|c|}
\hline \multicolumn{5}{|l|}{ Characiformes } \\
\hline \multicolumn{5}{|l|}{ ACESTRORHYNCHIDAE } \\
\hline Acestrorhynchus heterolepis (Cope, 1878) & 12 & 0.59 & $84-170$ & 一 \\
\hline Acestrorhynchus microlepis (Schomburgk, 1841) & 4 & 0.2 & $76-145$ & 一 \\
\hline \multicolumn{5}{|l|}{ ANOSTOMIDAE } \\
\hline Schizodon fasciatus Spix \& Agassiz, 1829 & 30 & 1.47 & $116-339$ & $\boldsymbol{\Delta}$ \\
\hline Laemolyta taeniata (Kner, 1859) & 11 & 0.54 & $90-136$ & - \\
\hline Laemolyta proxima (Garman, 1890) & 5 & 0.24 & $129-178$ & 一 \\
\hline Leporinus friderici (Bloch, 1794) & 3 & 0.15 & $128-141$ & - \\
\hline Rhytiodus argenteofuscus Kner, 1858 & 3 & 0.15 & $169-259$ & - \\
\hline Leporinus fasciatus (Bloch, 1794) & 2 & 0.1 & $118-125$ & 一 \\
\hline Leporinus trifasciatus Steindachner, 1876 & 2 & 0.1 & $85-129$ & - \\
\hline \multicolumn{5}{|l|}{ CHARACIDAE } \\
\hline Mylossoma duriventre (Cuvier, 1818) & 142 & 6.95 & $56-432$ & $\boldsymbol{\Delta}$ \\
\hline Triportheus angulatus (Spix \& Agassiz, 1829) & 123 & 6.02 & $67-417$ & $\boldsymbol{\Delta}$ \\
\hline Chalceus guaporensis Zanata \& Toledo-Piza, 2004 & 35 & 1.71 & $102-253$ & $\boldsymbol{\Delta}$ \\
\hline Triportheus albus Cope, 1872 & 32 & 1.57 & $114-339$ & $\boldsymbol{\Delta}$ \\
\hline Serrasalmus rhombeus (Linnaeus, 1766) & 15 & 0.73 & $103-413$ & - \\
\hline Triportheus auritus (Valenciennes, 1850) & 14 & 0.69 & $124-219$ & - \\
\hline Pygocentrus nattereri Kner, 1858 & 13 & 0.64 & $74-180$ & घ \\
\hline Tetragonopterus argenteus Cuvier, 1816 & 3 & 0.15 & $67-142$ & 一 \\
\hline Brycon amazonicus (Spix \& Agassiz, 1829) & 2 & 0.1 & $91-187$ & 一 \\
\hline Ctenobrycon hauxwellianus (Cope, 1870) & 2 & 0.1 & $127-131$ & 一 \\
\hline Parecbasis cycloleps Eigenmann, 1914 & 1 & 0.05 & 109 & 一 \\
\hline Catoprion mento (Cuvier, 1819) & 1 & 0.05 & 90 & 一 \\
\hline Colossoma macropomum (Cuvier, 1818) & 1 & 0.05 & 194 & 一 \\
\hline Cynopotamus amazonus (Günther, 1868) & 1 & 0.05 & 108 & 一 \\
\hline Cyphocharax notatus (Steindachner, 1908) & 1 & 0.05 & 109 & 一 \\
\hline Mylossoma aureum (Agassiz, 1829) & 1 & 0.05 & 134 & 一 \\
\hline \multicolumn{5}{|l|}{ CURIMATIDAE } \\
\hline Psectrogaster rutiloides (Kner, 1858) & 665 & 32.57 & $59-460$ & $\boldsymbol{\Delta}$ \\
\hline Potamorhina altamazonica (Cope, 1878) & 219 & 10.72 & $55-186$ & $\boldsymbol{\Delta}$ \\
\hline Potamorhina latior (Spix \& Agassiz, 1829) & 159 & 7.79 & $82-280$ & $\boldsymbol{\Delta}$ \\
\hline Psectrogaster amazonica Eigenmann \& Eigenmann, 1889 & 49 & 2.4 & $79-429$ & $\boldsymbol{\Delta}$ \\
\hline Curimatella meyeri (Steindachner, 1882) & 35 & 1.71 & $72-146$ & $\boldsymbol{\Delta}$ \\
\hline Curimata inornata Vari, 1989 & 4 & 0.2 & $120-138$ & घ \\
\hline Curimata vittata (Kner, 1858) & 2 & 0.1 & 119 & 一 \\
\hline Curimata kneri (Steindachner, 1876) & 1 & 0.05 & 130 & 一 \\
\hline \multicolumn{5}{|l|}{ CYNODONTIDAE } \\
\hline Rhaphiodon vulpinus Spix \& Agassiz, 1829 & 100 & 4.9 & $106-470$ & $\boldsymbol{\Delta}$ \\
\hline Hydrolycus scomberoides (Cuvier, 1816) & 6 & 0.29 & $110-156$ & घ \\
\hline Hydrolycus armatus (Jardine \& Schomburgk, 1841) & 3 & 0.15 & $129-143$ & 一 \\
\hline \multicolumn{5}{|l|}{ ENGRAULIDAE } \\
\hline Jurengraulis juruensis (Boulenger, 1898) & 1 & 0.05 & 126 & 一 \\
\hline \multicolumn{5}{|l|}{ ERYTHRINIDAE } \\
\hline Hoplias malabaricus (Bloch, 1794) & 2 & 0.1 & $117-119$ & 一 \\
\hline \multicolumn{5}{|l|}{ HEMIODONTIDAE } \\
\hline Anodus sp. & 12 & 0.59 & $66-179$ & - \\
\hline Hemiodus sp. & 8 & 0.39 & $123-241$ & घ \\
\hline
\end{tabular}




\begin{tabular}{|c|c|c|c|c|}
\hline Taxon & $\mathbf{N}$ & $\%$ & $\begin{array}{c}\text { Ls min-max } \\
(\mathrm{mm})\end{array}$ & Occurrence \\
\hline Anodus elongatus Agassiz, 1829 & 1 & 0.05 & 89 & - \\
\hline Hemiodus amazonum (Humboldt, 1821) & 1 & 0.05 & 134 & 一 \\
\hline \multicolumn{5}{|l|}{ PROCHILODONTIDAE } \\
\hline Prochilodus nigricans Agassiz, 1829 & 71 & 3.48 & $83-485$ & $\boldsymbol{\Delta}$ \\
\hline Semaprochilodus taeniurus (Valenciennes, 1817) & 1 & 0.05 & 138 & 一 \\
\hline \multicolumn{5}{|l|}{ Clupeiformes } \\
\hline \multicolumn{5}{|l|}{ PRISTIGASTERIDAE } \\
\hline Pellona flavipinnis (Valenciennes, 1836) & 9 & 0.44 & $124-140$ & 一 \\
\hline Pellona castelnaeana (Valenciennes, 1847) & 8 & 0.39 & $127-283$ & - \\
\hline \multicolumn{5}{|l|}{ Gymnotiformes } \\
\hline \multicolumn{5}{|l|}{ Apteronotidae } \\
\hline Apteronotus bonapartii (Castelnau, 1855) & 4 & 0.2 & 114-159 & - \\
\hline \multicolumn{5}{|l|}{ Perciformes } \\
\hline \multicolumn{5}{|l|}{ CICHLIDAE } \\
\hline Biotodoma cupido (Heckel, 1840) & 2 & 0.1 & $90-116$ & 一 \\
\hline Cichla monoculus Spix \& Agassiz, 1831 & 2 & 0.1 & $136-175$ & 一 \\
\hline Aequidens tetramerus (Heckel, 1840) & 1 & 0.05 & 305 & 一 \\
\hline Crenicichla johana Heckel, 1840 & 1 & 0.05 & 128 & 一 \\
\hline \multicolumn{5}{|l|}{ SCIAENIDAE } \\
\hline Plagioscion squamosissimus (Heckel, 1940) & 11 & 0.54 & $118-215$ & 一 \\
\hline \multicolumn{5}{|l|}{ Siluriformes } \\
\hline \multicolumn{5}{|l|}{ AUCHENIPTERIDAE } \\
\hline Auchenipterus ambyiacus Fowler, 1915 & 3 & 0.15 & $87-175$ & - \\
\hline Centromochlus heckelii (De Filippi, 1853) & 3 & 0.15 & $159-184$ & - \\
\hline \multicolumn{5}{|l|}{ CETOPSIDAE } \\
\hline Cetopsis coecutiens (Lichtenstein, 1819) & 1 & 0.05 & 160 & - \\
\hline \multicolumn{5}{|l|}{ DORADIDAE } \\
\hline Hemidoras stenopeltis (Kner, 1855) & 14 & 0.69 & $107-137$ & 一 \\
\hline Nemadoras humeralis (Kner, 1855) & 5 & 0.24 & $130-152$ & 一 \\
\hline Doras punctatus Kner, 1853 & 2 & 0.1 & $135-137$ & - \\
\hline \multicolumn{5}{|l|}{ LORICARIIDAE } \\
\hline Loricaria cataphracta Linnaeus, 1758 & 57 & 2.79 & $75-225$ & 一 \\
\hline Hypoptopoma gulare Cope, 1878 & 29 & 1.42 & $71-332$ & $\Delta$ \\
\hline Ancistrus sp. & 5 & 0.24 & $75-188$ & 一 \\
\hline Loricariichthys platymetopon Isbrücker \& Nijssen, 1979 & 3 & 0.15 & $189-217$ & 一 \\
\hline Peckoltia bachi (Boulenger, 1898) & 2 & 0.1 & 145 & - \\
\hline Hypostomus cf. emarginata (Valenciennes, 1840) & 1 & 0.05 & 215 & 一 \\
\hline Pseudorinelepis genibarbis (Valenciennes, 1840) & 1 & 0.05 & 199 & - \\
\hline Squaliforma emarginata (Valenciennes, 1840) & 1 & 0.05 & 153 & 一 \\
\hline Sturisoma robustum (Regan, 1904) & 1 & 0.05 & $153-160$ & 一 \\
\hline \multicolumn{5}{|l|}{ PIMELODIDAE } \\
\hline Sorubim lima (Bloch \& Schneider, 1801) & 36 & 1.76 & $99-256$ & $\boldsymbol{\Delta}$ \\
\hline Pimelodus aff. blochii Valenciennes, 1840 & 27 & 1.32 & $11-207$ & $\boldsymbol{\Delta}$ \\
\hline Sorubim elongatus Littmann, Burr, Schmidt \& Isern, 2001 & 9 & 0.44 & $109-253$ & - \\
\hline Calophysus macropterus (Lichtenstein, 1819) & 2 & 0.1 & $137-150$ & 一 \\
\hline Hypophthalmus edentatus Spix \& Agassiz, 1829 & 1 & 0.05 & 127 & 一 \\
\hline Hypophthalmus marginatus Valenciennes, 1840 & 1 & 0.05 & $153-301$ & 一 \\
\hline Leiarus pictus Müller \& Troschel, 1849 & 1 & 0.05 & 72 & - \\
\hline Total & 2.042 & & & \\
\hline
\end{tabular}


Table 2. Richness and total abundance of the Belmont stream fish assemblage by month and period, from May 2005 to April 2006.

Tabela 2. Riqueza e abundância total da assembléia de peixes do igarapé Belmont por mês e período, de Maio de 2005 a Abril de 2006.

\begin{tabular}{cccc}
\hline Period & Month & Richness & Abundance \\
\hline High & April & 26 & 93 \\
Falling & May & 24 & 109 \\
Falling & July & 23 & 89 \\
Low & August & 15 & 48 \\
Low & September & 17 & 517 \\
Rising & November & 27 & 231 \\
Rising & December & 16 & 419 \\
Rising & January & 19 & 276 \\
High & February & 29 & 217 \\
High & March & 14 & 43 \\
\hline
\end{tabular}
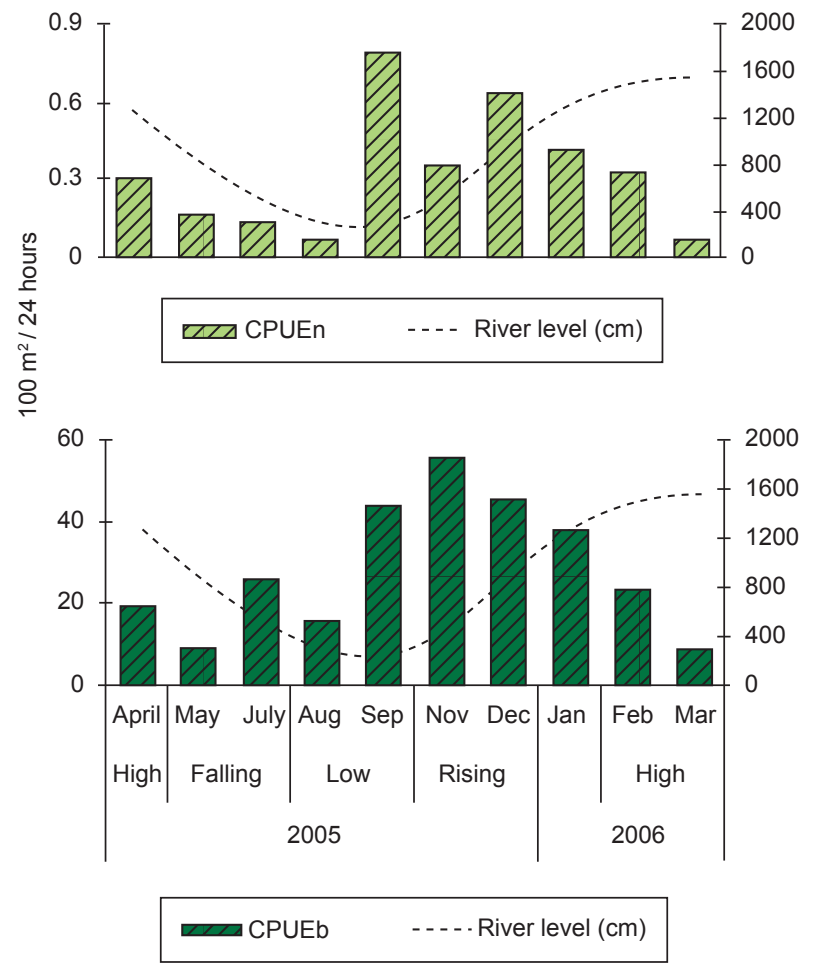

Figure 2. Catch per unit of effort (CPUE) according to fish abundance (CPUEn) and biomass (CPUEb) per 100/ $\mathrm{m}^{2} / 24$ hours in the sampling area, from May 2005 to April 2006.

Figura 2. Captura por unidade de esforço (CPUE) de acordo com a abundância de peixes (CPUEn) e biomassa (CPUEb) por 100/m²/24 horas na área de amostragem, de Maio de 2005 a Abril de 2006.

The presence of migratory species for the whole sampling period in Belmont maybe justified by the following arguments: 1. early or late ripe specimens are captured during all period; 2 . the specimens represent a portion of the population that would remain in the area or, for some unknown reason, would not complete the reproductive migration. The few numbers of small fishes in the samples lead to one of the two hypotheses above.
From September to December, there was an important increase in the water volume and disponibility of flooded area for fish dispersal (Lowe-McConnell 1999); the river water level increased $416 \mathrm{~cm}$ simultaneously to an increase in the CPUE $\mathrm{E}_{\mathrm{b}}$ in November. This fact may represent heavier ripe fishes ready for reproduction which was reported by Torrente-Vilara et al. (2005).

Detritivorous fishes composed $60 \%$ of the assemblage, four of them from Curimatidae family. A small flooded area is observed along the Madeira River stretch (Goulding 1979) and the sediment associated with the organic particles in the Madeira River could play an important role in the local trophic structure (Vadeboncoeur 2002).

Santo Antonio is the first fall upstream Belmont and an important route to migratory fishes in Madeira River (Goulding 1979). Curimatidae species that annually perform migrations are constant in this area and because of some biological or ecological reason; do not swim up the fast-flowing areas of the Madeira River rapids. Perhaps these individuals remain in the tributaries downstream near the falls, taking advantage of temporary environments. However, these hypotheses must be carefully investigated.

\section{Acknowledgements}

We are grateful to the Biogeochemical Laboratory of the Federal University of Rondônia (W. Bastos), the researchers and students who directly or indirectly contributed to the research activities of the "Ecology and Biology of Fish Communities in Belmont Stream, Porto Velho - RO" project (process n ${ }^{\circ}$ 553057/2005-7), Dr. Jansen Zuanon for his help in identifying the species, Dr. Rosseval for the suggestions to the manuscript, "Ação Ecológica no Guaporé" (ECOPORÉ), and $\mathrm{CNPq}$, who provided a grant to the first author.

\section{References}

ALMEIDA, V.L.L., HAHN, N.S. \& VAZZOLER, A.E.A.M. 1997. Feeding patterns in fivepredatory fishes of the high Paraná River floodplain (PR, Brazil). Ecol. Freshw. Fish. 1007(6):123-133.

BARTHEM, R.B., GOULDING, M., FORSBERG, B., CANAS, C. \& ORTEGA, H. 2003. Ecología acuática del Rio Madre de Dios: bases científicas para la conservación de cabeceras andino-amazónicas. ACCA, Lima.

BASTOS, W.R., ALMEIDA, R., DÓREA, J.G. \& BARBOSA, A.C. 2007. Annual flooding and fish-mercury bioaccumulation in the environmentally impacted Rio Madeira (Amazon). Ecotoxicol. 16(3):341-346.

BITTENCOURT, M.M. \& AMADIO, S.A. 2005. Proposta para identificação rápida dos períodos hidrológicos em áreas de várzea do rio SolimõesAmazonas nas proximidades de Manaus. Acta Amaz. 37(2):303-308.

BÖHLKE, J.E., WEITZMAN, S.H. \& MENEZES, N.A. 1978. Estado atual da sistemática dos peixes de água doce da América do Sul. Acta Amaz. 8(4):657-677.

BRITSKI, H.A. 1999. Peixes do Pantanal: manual de identificação. Embrapa, Brasília.

CAMARGO, M. \& GIARRIZZO, T. 2007. Fish, Marmelos Conservation Area (BX044), Madeira River basin, states of Amazonas and Rondônia, Brazil. Check List. 3(4):291-296.

CARVALHO, L.N. 2008. História natural de peixes de igarapés amazônicos: utilizando a abordagem do conceito de rio contínuo. Tese de Doutorado, Instituto Nacional de Pesquisas da Amazônia, Manaus.

CASATTI, L. \& CASTRO, R.M.C. 2006. Testing the ecomorphological hypothesis in a headwater riffles fish assemblage of the rio São Francisco, southeastern Brazil. Neotrop. Ichthyol. 4(2):203-214.

CASTRO, R.M.C. 1999. Evolução da ictiofauna de riachos sul-americanos: padrões gerais e possíveis processos casuais. In Ecologia de peixes de riachos (E.P. Caramaschi, R. Mazzoni \& P.R. Peres-Neto, eds). UFRJ, Rio de Janeiro, p. 139-155. (Série Oecologia Brasiliensi).

DAJOZ, R. 1973. Ecologia geral. Vozes, São Paulo. 
ESPÍRITO SANTO, H.M.V., MAGNUSSON, W.E., ZUANON, J.A.S., MENDONCA, F.P. \&

LANDEIRO, V.L. 2009 Seasonal variation in fish composition of fish assemblages in small Amazonian forest streams: evidence for predictable changes. Fresh. Biol. 54(3):536-548.

FERNANDES, C.C. 1997. Lateral migration of fishes in Amazon floodplains. Ecol. Freshw. Fish. 6(1):36-44.

FERREIRA, E.J.G., SANTOS, G.M., LEÃO, E.L.M. \& OLIVEIRA, L.A. 1993. Bases científicas para estratégias de preservação e desenvolvimento da Amazônia. INPA, Manaus.

FERREIRA, E.J.G., ZUANON, J.A.S. \& SANTOS, G.M. 1998. Peixes comerciais do Médio Amazonas: região de Santarém, Pará. IBAMA, Brasília.

FURCH, K. \& JUNK, W.J. 1997. Physicochemical conditions in the floodplains. In The Central Amazon floodplain. Ecology of a pulsing system (W.J. Junk, ed.). Ecol. Stud. 126(1):69-108.

GARUTTI, V. 1988. Distribuição longitudinal da ictiofauna em um córrego da região noroeste do Estado de São Paulo, bacia do Paraná. Rev. Bras. Biol. 48(4):747-759.

GOULDING, M. 1979. Ecologia da pesca do rio Madeira. INPA, Manaus.

GOULDING, M. 1980. The fishes and the forest: Explorations in Amazonian Natural History. University of California Press, Berkeley.

GOULDING, M. 1988. Ecology and management of migratory food fishes of the Amazon Basin. In Tropical rainforests, diversity and conservation. (F. Almeda \& C.M. Pringie, eds.). California Academy of Sciences \& Pacific Division of the American Association for the Advancement of Science, San Francisco, p. 71-85.

GOULDING, M., BARTHEM, R. \& FERREIRA, E. 2003. The Smithsonian atlas of the Amazon. Smithsonian Books, Washington D.C.

HAHN, N.S., AGOSTINHO, A.A., GOMES, L.C. \& BINI, L.M. 1998. Estrutura trófica da ictiofauna do reservatório de Itaipu (Paraná-Brasil) nos primeiros anos de sua formação. Interciencia. 23(5):299-305.

HONDA, E.M.S. 1974. Contribuição ao conhecimento da biologia de peixes do Amazonas II: alimentação de tambaqui, Colossoma bidens (Spix). Acta Amaz. 4(2):47-53.

JUNK, W.J., SOARES, G.M. \& CARVALHO, F.M. 1983. Distribution of fish species in a lake of the Amazon River floodplain near Manaus (Lago Camaleão), with species reference to extreme oxygen conditions. Amazoniana. 7(4):397-431.

KELLER, F. 1874. The Amazon and Madeira rivers, sketches and descriptions from the note-book of an explorer. Chapman \& Hall, London.

LAUZANNE, L. \& LOUBENS, G. 1985. Peces del rio Mamore. Éditions de I'Orstom, Paris, p. 58-97. (Collection Travaux et Documents n. 192).

LAuZAnne, L., LOUBEnS, G. \& GUENNEC, B.L.E. 1990. Pesca y biología pesquera en el Mamoré médio (región de Trinidad, Bolívia). Interciencia. 15(6):452-460.

LATRUBESSE, E., STEVAUX, J.C. \& SINHA, R. 2005. Tropical rivers. Geomorphol. 70(2005):187-206.

LOUBENS G., LAUZANNE, L. \& LE GUENNEC, B. 1992. Lês milieux aquatiques de la région de Trinidad Béni, Amazonie bolivienne. Rev. d'Hydrob. Trop. 25(1):3-21.

LOWE-McCONNEL, R.H. 1999. Estudos ecológicos de comunidades de peixes tropicais. In

(A.E.A.M. Vazzoler, A.A. Agostinho \& P.T.M. Cunnhingham, trad.). EDUSP, São Paulo.

MATTHEWS, W.J. 1998. Patterns in freshwater fish ecology. Chapman \& Hall, New York.

McClAIN, M.E., RICKEY, J.E. \& VICTORIA, R.I. 1995. Andean contributions to the biogeochemistry of the Amazon river system. Bull. Inst. fr. étud. andin. 24(3):1-13

MENDONÇA, F.P., MAGNUSSON, W.E. \& ZUANON, J.A.S. 2005. Relationships between habitat characteristics and fish assemblages in small streams of Central Amazonia. Copeia. 2005(4):750-763.
MENEZES, J.M. 2007. Variação espacial e sazonal de aspectos limnologicos associada ao uso e ocupação da micro-bacia do igarapé Belmont. Porto Velho/Rondônia/Amazônia Ocidental. Monografia, Universidade Federal de Rondônia, Rondônia.

MERONA, B. \& BITTENCOURT, M.M. 1993. Les peuplements de poisons du "Lago do Rei", un lac d'inundation d'Amazonie centrale: description générale. Amazoniana. 12(3-4):415-441.

MIRANDA, J.C. \& MAZZONI, R. 2003. Composição da ictiofauna de três riachos do alto rio Tocantins-GO. Biot. Neotrop. 3(1):http://www. biotaneotropica.org.br/v3n1/pt/abstract?article+BN00603012003. (último acesso em 08/10/2008)

NELSON, J.S. 1994. Fishes of the world. 3 ed. John Wiley \& Sons, New York.

PAVANELLI, C. \& CARAMASCHI, E.P. 1997. Composition of the ichthyofauna of two small tributaries of the Paraná River, Porto Rico, Paraná State, Brazil. Ichthyol. Explor. Fresh. 8(1):23-31.

PAZIN, V.F.V., MAGNUSSON, W.E., ZUANON, J.A.S. \& MENDONÇA, F.P. 2006. Fish assemblages in temporary ponds adjacent to terra-firme streams in central Amazonia. Fresh. Biol. 51(6):1025-1037.

PENCZAK, T., AGOSTINHO, A.A. \& OKADA, E.K. 1994. Fish diversity and community structure in two small tributary of the Paraná River, Paraná State, Brazil. Hydrobiol. 294(3):243-251.

POUILLY, M., LINO, F., BRETENOUX, J.G. \& ROSALES, C. 2003. Dietary-morphological relationships in a fish assemblage of the Bolivian Amazonian floodplain. J. Fish. Biol. 63(5):1137-1158.

POUILLY, M. \& MIRANDA, G. 2003. Morphology and reproduction of the cavefish Trichomycterus chaberti and the related epigean Trichomycterus cf. barbouri. J. Fish Biol. 63(2):490-505.

POUILLY, M., YUNOKI T., ROSALES, C. \& TORRES, L. 2004. Trophic structure of fish assemblages from Mamoré River floodplain lakes (Bolivia). Ecol. Freshw. Fish. 13(4):245-257.

POUILLY, M. \& RODRÍGUEZ, M.A. 2004. Determinism of fish assemblage structure in neotropical floodplain lakes: Influence of internal and landscape lake conditions. In Proceedings of the Second International Symposium on the Management of Large Rivers for Fisheries (R. Welcomme \& T. Petr, coords.). FAO, Bangkok, p. 243-265.

RAPP PY-DANIEL, L.H., DEUS, C.P., RIBEIRO, O.M \& SOUSA, L.M. 2007. Peixes. In Biodiversidade do Médio Madeira: bases científicas para proposta de conservação (L.H. Rapp Py-Daniel, C. P. Deus, A.L. Henriques, D. M. Pimpão \& O.M. Ribeiro, orgs.). MMA/MCT, Manaus, p. 89-125.

ROBERTS, T. 1972. Ecology of fishes in the Amazon and Congo basins. Bull. Mus. Comp. Zool. 143(2):117-147.

ROBINSON, J.L. \& RAND, P.S. 2005. Discontinuity in fish assemblages across an elevation gradient in a southern Appalachian watershed, USA. Ecol. Freshw. Fish. 14(1):14-23.

SABINO, J. \& ZUANON. J.A.S. 1998. A stream fish assemblage in Central Amazonia: distribution, activity patterns and feeding behavior. Ichthyol. Explor. Fresh. 8(3):201-210.

SAINT-PAUL, U., ZUANON, J., CORREA, M.A.V., GARCIA, M., FABRE, N.N., BERGER, U. \& JUNK, W.J. 2000. Fish communities in central Amazonian white- and blackwater floodplains. Environ. Biol. Fish. 57(3):235-250.

SANTOS, G.M. 1986. Composição do pescado e situação da pesca no estado de Rondônia. Acta Amaz. 16/17(suplemento): 43-84.

SANTOS, G. M. 1991. Pesca e ecologia dos peixes de Rondônia. Tese de Doutorado, Instituto Nacional de Pesquisas da Amazônia, Manaus.

SANTOS, G.M., FERREIRA, E. \& ZUANON, J. 2006. Peixes comerciais de Manaus. 1 ed. IBAMA, Manaus, p. 53-55.

SILVA DIAS, M.A.F., COHEN, J.C.P. \& GANDÚ, A.W. 2005. Interações entre nuvens, chuvas e a biosfera na Amazônia. Acta Amaz. 35(2):215-222.

SIQUEIRA-SOUZA, F.K. \& FREITAS, C.E.C. 2004. Fish diversity of floodplain lakes on the lower stretch of the Solimões River. Braz. J. Biol. 64(3A):501-510. 
SOARES, M.G.M., ALMEIDA, R.G. \& JUNK, W.J. 1986. The trophic status of the fish fauna in Lago Camaleão, a macrophyte dominated floodplain lake in the middle Amazon. Amazoniana. 9(4):511-526.

SOARES, J.L. 1993. Dicionário etimológico e circunstanciado de biologia. Scipione, São Paulo.

SOUZA-FILHO, P.W.M., QUADROS, M.L.E.S., SCANDOLARA, J.E., FILHO, E.F.S. \& REIS,

M.R. 1999. Compartimentação morfoestrutural e neotectônica do sistema fluvial Guaporé-Mamoré-Alto Madeira, Rondônia - Brasil. Rev. Bras. Geo. 29(4):469-476.

TORRENTE-VILARA, G., ZUANON, J., DORIA, C.R.C., ARAÚJO, T.R., FÁVARO, L.F. \&

LEITE, R.G. Diagnóstico ambiental da área de influência direta, meio biótico, ictiofauna e recursos pesqueiros: estudo de impacto ambiental dos aproveitamentos hidrelétricos Santo Antonio e Jirau, rio Madeira-RO: relatório técnico final. In Área de influência direta dos aproveitamentos hidrelétricos de Jirau e Santo Antonio (LEME Engenharia S.A., org). Tomo B(5):755-916.

TORRENTE-VILARA, G., ZUANON, J.A.S., AMADIO, S.A. \& DÓRIA C.R.C. 2008. Biological and ecological characteristics of Roestes molossus (Teleostei: Cynodontidae), a night hunting characiform fish from upper Madeira River, Brazil. Ichthyol. Explor. Fresh. 19(2):103-110.

UIEDA, V.S. 1984. Ocorrência e distribuição dos peixes em um riacho de água doce. Rev. Brasil. Biol. 44(2):203-213.

VADEBONCOEUR, M.J., VANDER, Z. \& LODGE, D.M. 2002. Putting the lake back together: Reintegrating benthic pathways into lake food web models. Biosci. 52(1):44-55.
VIANA, J.P. 1999. The effects of a hydroelectric dam on fish in an Amazonian river. Tese de Doutorado, University of Florida, Florida.

VIEIRA, I. \& GERY, J. 1979. Crescimento diferencial e nutrição em Catoprion mento (Characoidei). Peises lepidofago da Amazonia. Acta Amaz. 9(1):143-146.

WALKER, I. 1991. Algumas considerações sobre um programa de zoneamento da Amazônia. In Bases científicas para estratégias de preservação e desenvolvimento da Amazônia (A.L. Val, R. Figliuolo \& E. Feldberg, eds). Instituto Nacional de Pesquisas da Amazônia, Manaus, p. 37-46.

WALKER, I. 1995. Amazonian streams and small rivers. In Limnology in Brasil (J.G. Tundisi, C.E. Bicudo \& T. Matsumura-Tundisi, eds.) Academia Brasileira de Ciência, Rio de Janeiro, p. 167-193.

WETZEL, R.G. 1975. Limnology. Saunders College Publications, Philadelphia.

YAMAMOTO, K.C., SOARES, M.G.M. \& FREITAS, C.E.C. 2004. Alimentação de Triportheus angulatus (Spix \& Agassiz, 1829) no lago Camaleão, Manaus, AM, Brasil. Acta Amaz. 34(4):253-259.

YOSSA, M.I. \& ARAÚJO-LIMA, C.A.R.M. 1998. Detritivory in two Amazonian fish species. J. Fish. Biol. 52(6):1141-1153.

ZANATA, A.M. \& TOLEDO-PIZA, M. 2004. Taxonomic revision of the South American fish genus Chalceus Cuvier (Teleostei: Ostariophysi: Characiformes) with the description of three new species. Zool. J. Linn. Soc. 140(1):103-135. 